$\xi=-1$

\title{
A new approach to achieve a fast acting MPPT technique for solar photovoltaic system under fast varying solar radiation
}

\author{
T. Vijay Muni ${ }^{1}$ *, S V N L Lalitha ${ }^{1}$, B. Krishna Suma ${ }^{1}$, B. Venkateswaramma ${ }^{1}$ \\ ${ }^{1}$ Department of Electrical and Electronics Engineering, Koneru Lakshmaiah Education Foundation. Vaddeswaram, Guntur, Andhra \\ Pradesh, India \\ *Corresponding author E-mail: vijaymuni1986@gmail.com
}

\begin{abstract}
In this paper, a new control technique is proposed to achieve a fast acting Maximum Power Point Tracking (MPPT) Technique for solar photovoltaic system under fast varying solar radiation. Conventional MPPT techniques in PV systems fail to track maximum power point (MPP) under fast varying of sunlight levels. In the proposed MPPT algorithm a fine tuned duty cycle for a DC-DC converter is achieved to avoid the divergence of MPP. This can be achieved from the relationship between the load line and the MPP locus. The MPPT algorithm is used to regulate the duty cycle of a DC-DC converter to ensure that always the load line cuts the I-V curve at MPP. The effectiveness of the proposed PV-MPPT system is demonstrated via case studies and simulation results shows the effective performance of the fast acting MPPT technique in achieving efficient MPP.
\end{abstract}

Keywords: Solar PV System; MPPT Algorithm; DC-DC Converter; Load Resistance; Varying Solar Radiation.

\section{Introduction}

The development of a country is generally measured by the progress in electricity sector. Fossil fuels which are major contributors to electric power generation are not only haste depleting but also contribute towards global warming [1]. India stands fifth among the countries having huge coal reserves, but the electricity demands are growing manifold where demand is unable to meet the supply. India's per capita power consumption is only around $1010 \mathrm{kWh}$ in 2014-2015, which is very low compared with other developed nations. A paradigm shift on using alternative energy sources is inevitable as these sources balance the fossil fuel demand; moreover they pave the path towards cleaner power generation systems. India which has tropical climatic conditions is honored with a sun insolation of 4 to $7 \mathrm{kWh} / \mathrm{m} 2 /$ day on an average. Photovoltaic (PV) energy production has gotten uncommon consideration these days as one of the significant energy wellsprings without bounds in light of its adaptable design, less fuel cost and eco-accommodating nature [2].

Generally, the power from the solar which is non depleting in nature is stochastic and highly fluctuating. There are various factors on which the non conventional energy production depends on temperature, shading effect and much more internal factors, etc [3], [4]. The maximum energy production that is power should be extracted from the solar panel in the given conditions. This process is called maximum powerpoint tracking. The point at each the proposed aim is reached, is called point of maximum power. The efficiency of the entire photovoltaic energy generation depends on the operating characteristic point. The load should ultimately get the optimum possible power obtained from the photovoltaic generation at the operating characteristic point [5]. Therefore, there should be some control logic or control technique in form of a suitable controller which is designated as maximum power point tracking (MPPT) controller. This controller is designed in such a way that the maximum power is obtained from the photovoltaic module.

Incremental conductance along with Perturb and Observe $(\mathrm{P} \& \mathrm{O})$ are few among the many of the algorithms which are designed to extract the maximum power which doesnot limit to fractional open circuit voltage based algorithm, hill climbing algorithm, fractional short circuit current based MPPT algorithm, fuzzy logic, neural network based advanced hybrid MPPT algorithms[6]-[19]. The main principle behind the MPPT design is regulating the switching instants and operation of a dc-dc converter located at the photovoltaic module to ensure that system operates at the operating characteristic point that is maximum power point (MPP) [20].

The P\&O strategy [21] is an iterative calculation to track the MPP by estimating the current and voltage of the PV module. This calculation is anything but difficult to execute, yet the issue of swaying of working point around MPP is unavoidable [22]. Incremental conductance (INC) technique exhibited in [23] is most broadly utilized strategy. It tracks the MPP by contrasting quick conductance with the incremental conductance. The INC strategy requires complex calculations to gain great exactness under quickly changing climate conditions and the reaction time to achieve MPP is additionally moderately [24].

The $\mathrm{P} \& \mathrm{O}$ and INC calculations have unpredictable conduct if there should be an occurrence of quickly evolving light. Both $\mathrm{P} \& \mathrm{O}$ and INC can't recognize a neighborhood most extreme from a worldwide greatest. In the event of shaded conditions, these nearby maxima do happen in the V-P normal for a sun based board and working at a neighborhood most extreme could mean decreased power yield[25]-[27]. The previously mentioned calculations work agreeably just under uniform illumination conditions in which PV bend has a one of a kind MPP [28]. 
At the point when there is variety in the sun based light level or load protection, the reactions of settled advance size calculation are moderate. Consequently, factor step estimate calculations are presented [20], [29], [30]. These calculations utilize the incline of the $\mathrm{P}-\mathrm{V}$ bend in the obligation cycle annoyance. Be that as it may, the progression estimate winds up littler when the calculations near the pinnacle of the $\mathrm{P}-\mathrm{V}$ bend, and the union of the framework is likewise slower.

A couple of altered calculations have been acquainted with enhance the focalizing speed amid the variety in sun based illumination level and load. The connection between the heap line and the MPP locus is utilized as a part of [31]- [33] to exhibit a quick uniting calculation. The MPP locus is a line which around associates all the MPP for all levels of sun powered light.

\section{System modeling}

\subsection{Mathematical model of PV array}

A photovoltaic framework changes over sun power into usable electric power. The PV innovation utilizes photovoltaic cells which ingests photons of light and discharge electron charges. A few PV cells are associated in arrangement and parallel blend constitutes a PV board or PV module to deliver wanted yield control. The inverter is utilized to change over the DC control into AC. The vitality separated from the PV framework is one of the dependable characteristic vitality sources on account of its eco agreeable nature. To accomplish the most extreme proficiency, it is important to separate the greatest power from the PV panels. The basic comparable circuit of a PV cell comprises of a perfect current source in parallel with a perfect diode is appeared in Figure 1.

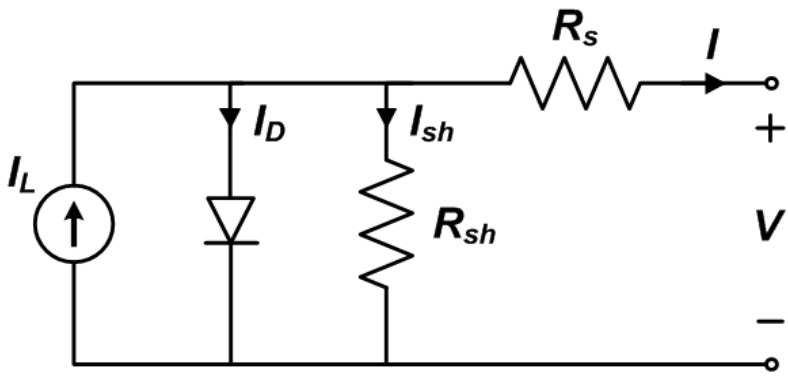

Fig. 1: Equivalent Model of the PV Cell.

For a perfect PV cell, Rs $=0$ (no arrangement misfortune) and Rsh $=$ limitless (no spillage to ground). The typical values of $\mathrm{RS}=0: 05$ to $0.10 \Omega$ and $\mathrm{Rsh}=200$ to $300 \Omega$. Internal resistance to the current is determined Rs which is the resistance connected in series. Rsh which varies indirectly to the ground leakage current is the resistance connected in shunt mode. The power transformation proficiency of PV cell is delicate to little varieties in Rs, however is obtuse to varieties in Rsh. A little increment in Rs can diminish the PV yield essentially.

The solar cell is mathematically modeled and developed based on the following equations [10].

$$
I=I_{L}-I_{D}-I_{s h}
$$

Where,

$\mathrm{I}_{L}$ current obtained through light or Photocurrent

$\mathrm{I}_{D}$, Current passing through the diode

$\mathrm{I}_{s h}$, current flowing the resistance connected in shunt, leakage current.

$$
I=I_{L}-I_{\text {ocell }}\left(e^{\frac{q^{*} k^{*}}{\alpha k^{*} T}}-1\right)
$$

Where,

$\mathrm{k}:$ Boltzmann constant $\left[1.3806503 \times 10^{-23} \mathrm{~J} / \mathrm{k}\right]$

$\mathrm{T}:$ Temperature.
$\mathrm{I}_{0, \text { cell }}$ : Reverse saturation current $[\mathrm{A}]$.

q: Electron charge $\left[1.60217646 \times 10^{-19} \mathrm{c}\right]$.

$\alpha$ : Diode identity factor

\subsection{Irradiance and solar radiation}

Irradiance is a momentary measurement portraying the motion of sun powered radiation occurrence on a surface $(\mathrm{kW} / \mathrm{m} 2)$. The thickness of energy radiation from the sun at the external air is $1.373 \mathrm{~kW} / \mathrm{m} 2$, however just a pinnacle thickness of $1 \mathrm{~kW} / \mathrm{m} 2$ is the last occurrence daylight on earth's surface. Light measures sun based radiation vitality got on a given surface zone in a given time. It is the time indispensable of irradiance. For instance, every day illumination can be surrendered to $\mathrm{kWh} / \mathrm{m} 2$ every day. Insolation is another name for light. Alluding to a standard irradiance of $1000 \mathrm{~W} / \mathrm{m} 2$, insolation is typically given in hours. Figure 2 gives the connection amongst irradiance and insolation.

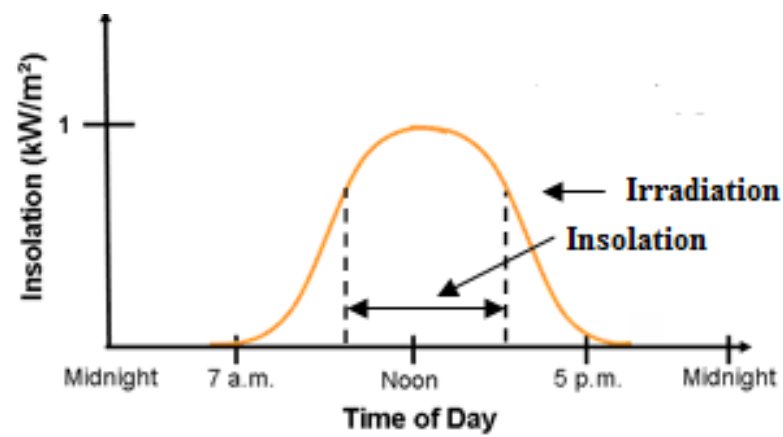

Fig. 2: Solar Irradiance and Solar Insolation Photons Carrying Energy $E_{p h}$ Which Is the Main Component in Solar Radiation Represented As

$$
E_{p h}=h \frac{c}{\lambda}
$$

Where,

$\lambda$ is the wavelength of the solar radiation,

$h$ is the Plank's constant and

$c$ is the light velocity .

Global radiation comprises three components:

- Reflected radiation from the ground

- Diffuse radiation scattered by the atmosphere and clouds.

- Direct solar radiation: The sun radiation received directly from the sun.

The estimations of sun based irradiance are taken utilizing either a pyranometer for worldwide radiation or a pyrheliometer for coordinate radiation. The essential of sun oriented irradiance over a day and age is sun based illumination.

\subsection{I-V and P-V characteristics}

The V-I bend of the BP SX 150S PV module recreated with the MATLAB demonstrate as indicated Figure 3. The V-I bend of PV module has exceptional working point called greatest power point (MPP). The directions of this working point are the working voltage and current. At this MPP, the module works with the most extreme productivity and produces the greatest photovoltaic yield.

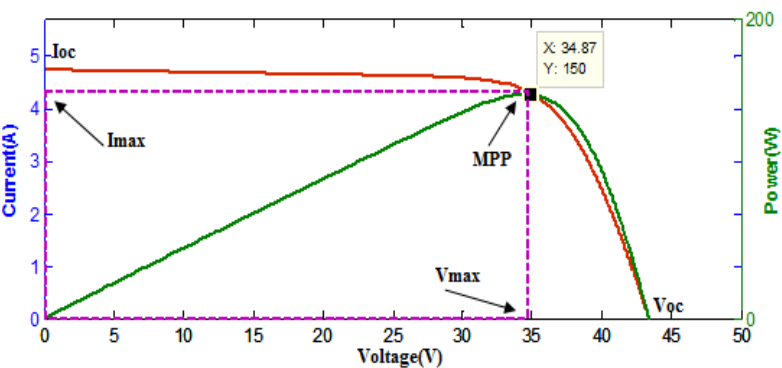

Fig. 3: V-I Curves of BPSX 150s PV Module with MPP. 


\subsection{Maximum power point tracking algorithm}

The photovoltaic yield or energy production is an endless and clean energy reservoir or replenishing asset. Be that as it may, the capital cost of PV establishment is high. Consequently, it is important to augment the yield control without expanding the quantity of PV modules. The yield control from the PV cluster shifts with sunlight based irradiance and temperature. In this manner, to amplify the productivity of the sustainable power source framework, it is important to track the most extreme power purpose of the PV exhibit talked about in [34], [35]. The PV cluster has a remarkable working point that can supply greatest energy to the heap. This point is known as the most extreme power point (MPP). The locus of this point has a nonlinear variety with sun powered irradiance and the cell temperature. Along these lines, keeping in mind the end goal to work the PV cluster at its MPP, the PV framework must contain a most extreme power point following (MPPT) controller.

In MPPT controller, obligation cycle is the control parameter. The MPPT controller tune the obligation cycle $(\alpha)$ to its ideal incentive under varieties in sun powered irradiance and temperature. The MPPT circuit comprises of energy circuit and the controller. The two setups of MPPT plot are appeared in Figure 4.

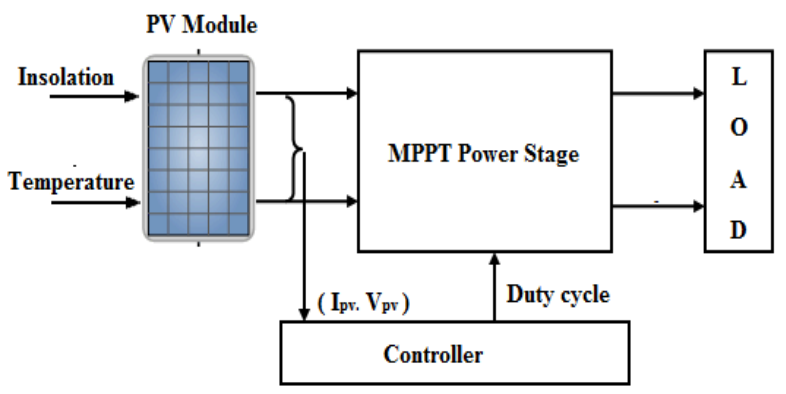

Fig. 4: MPPT Control through Input Parameters.

\section{Proposed MPPT algorithm}

Usually the photovoltaic module is cascaded with the load using the DC-DC converter. The switching operation or duty cycle is optimized in such a way that the load line always cuts the I-V curve at maximum power point (MPP) as shown in figure 5 .

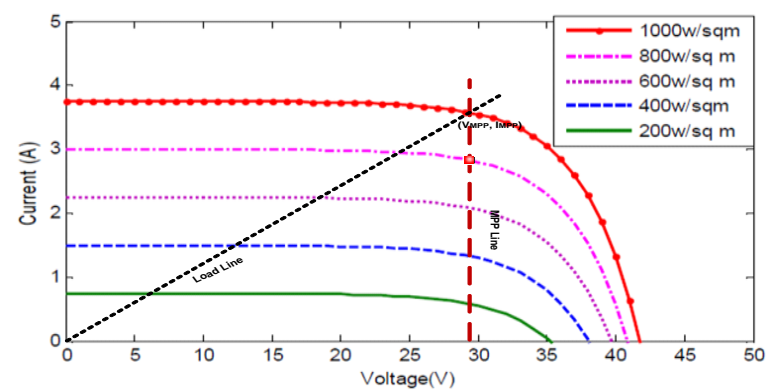

Fig. 5: Load Line and MPP Line on I-V Curve.

Under various levels of sun based radiation, PV module produces distinctive power levels. If there is increment or decline in sunlight based radiation both the voltage and current of PV module differs at the same time. Figure 6 demonstrates the main block diagram of the proposed PV framework as discussed in [36].

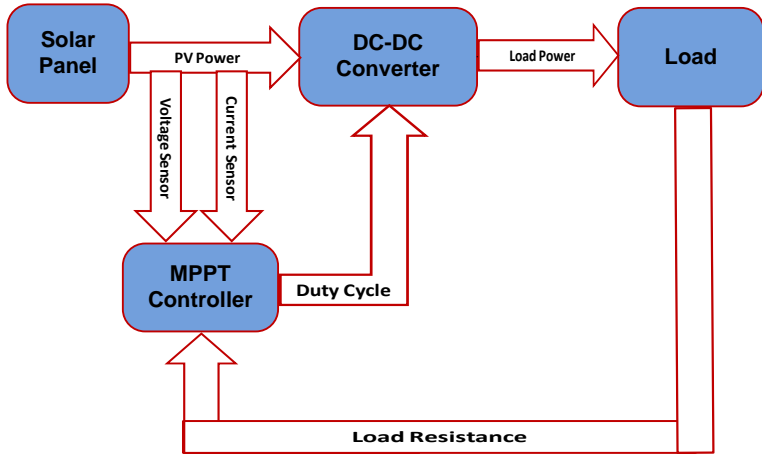

Fig. 6: Proposed System with MPPT Algorithm.

The relation between the input and output voltage for DC-DC buck boost converter is

$$
\begin{gathered}
V_{\text {ipput }}=\frac{1-D}{D} V_{\text {oupput }} \\
I_{\text {ipput }}=\frac{1-D}{D} I_{\text {oupput }}
\end{gathered}
$$

Divide (1) with (2)

$$
R_{\text {input }}=\frac{(1-D)^{2}}{D^{2}} R_{\text {ouput }}
$$

Where,

$R_{\text {input }}$ is the input resistance of converter or resistance offered by PV module

$R_{\text {ouppu }}$ is the output resistance of converter or load resistance

From (3) it is noticed that duty cycle can be regulated to force the input resistance of the converter to be varied until the load line cuts the I-V curve at MPP.

$$
\frac{D^{2}}{(1-D)^{2}}=\frac{R_{\text {input }}}{R_{\text {oupput }}}
$$

Load resistance can be calculated at any operating MPP by substituting the duty cycle, PV voltage and PV current in (4). After obtain the load resistance value, (4) can be rewritten as

$$
D=\frac{\sqrt{\frac{I_{P V} R_{\text {lood }}}{V_{P V}}}}{1+\sqrt{\frac{I_{P V}}{V_{P V}} R_{\text {lood }}}}
$$

Then duty cycle is obtained from (5)

\subsection{Variation of load}

If there is a load variation, the MPP of the PV module diverts and load line does not cut the MPP, then new duty cycle is required to operate the PV module at MPP. As there is variation only in load, the voltage and current at the MPP is same.

Thus by using the ( ) new resistance of load can be obtained

$$
R_{\text {lood }}=\frac{D^{2}}{(1-D)^{2}} \frac{V_{P V}}{I_{P V}}
$$

Then substituting the $\mathrm{V}_{\mathrm{PV}}$ and $\mathrm{I}_{\mathrm{PV}}$ at the MPP in (), the new duty cycle can be calculated 


$$
D=\frac{\sqrt{\frac{I_{P V}}{V_{P V}} R_{\text {loal }}}}{1+\sqrt{\frac{I_{P V}}{V_{P V}} R_{\text {lood }}}}
$$

Then the PV module operates at the point very close to new MPP.

\subsection{Decrease in solar radiation}

Initially if the PV module is operating at $800 \mathrm{~W} / \mathrm{m}^{2}$ and load line 4 , the operating MPP is at point A as shown in figure. Then if the solar radiation is decreased to $200 \mathrm{~W} / \mathrm{m}^{2}$, load line 4 cuts the I-V curve at point $\mathrm{B}$, which is far away from the MPP of $200 \mathrm{~W} / \mathrm{m}^{2}$, point $\mathrm{C}$. The new MPP is calculated by using the equation

$$
D=\frac{\sqrt{\frac{I_{P V}}{V_{P V}} R_{\text {load }}}}{1+\sqrt{\frac{I_{P V}}{V_{P V}} R_{\text {loat }}}}
$$

But for calculation of $\mathrm{D}$, the voltage, current of PV module and load resistance of the new MPP is required. $\mathrm{I}_{\mathrm{PV}}$ is estimated by direct estimation method and it always operates at 0.8 times of short circuit current $\left(I_{\mathrm{sc}}\right)$ at decreased radiation. $V_{\mathrm{pv}}$ always operates at $\mathrm{V}_{\mathrm{MPP}}$ of previous point $\left(\mathrm{V}_{\mathrm{pv}}\right.$ at point $\left.\mathrm{A}\right)$.

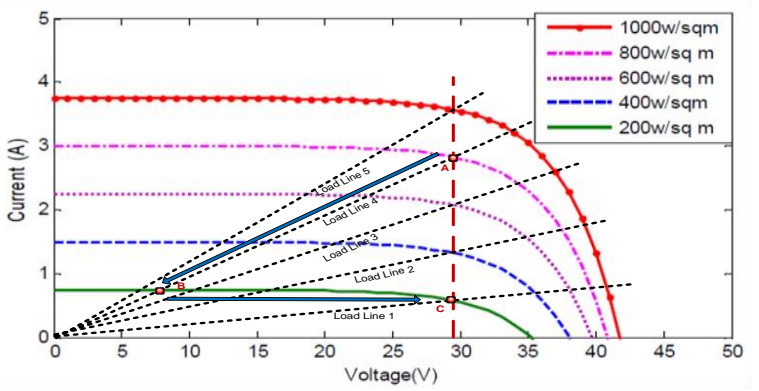

Fig. 7: Proposed Algorithm for Decrease in Solar Radiation.

\subsection{Increase in solar radiation}

Initially if the PV module is operating at $200 \mathrm{~W} / \mathrm{m}^{2}$ and load line 1 , the operating MPP is at point A as shown in figure. Then if the solar radiation is increased to $800 \mathrm{~W} / \mathrm{m}^{2}$, load line 1 cuts the $\mathrm{I}-\mathrm{V}$ curve at point $\mathrm{B}$, which is far away from the MPP of $800 \mathrm{~W} / \mathrm{m}^{2}$, point $\mathrm{C}$. The new MPP is calculated by using the equation.

$$
D=\frac{\sqrt{\frac{I_{P V}}{V_{P V}} R_{\text {lood }}}}{1+\sqrt{\frac{I_{P V}}{V_{P V}} R_{\text {load }}}}
$$

Where $I_{P V}$ is the short circuit current at increased radiation, $V_{p v}$ always operates at $\mathrm{V}_{\text {MPP }}$ of previous point $\left(\mathrm{V}_{\mathrm{pv}}\right.$ at point $\left.\mathrm{A}\right)$.

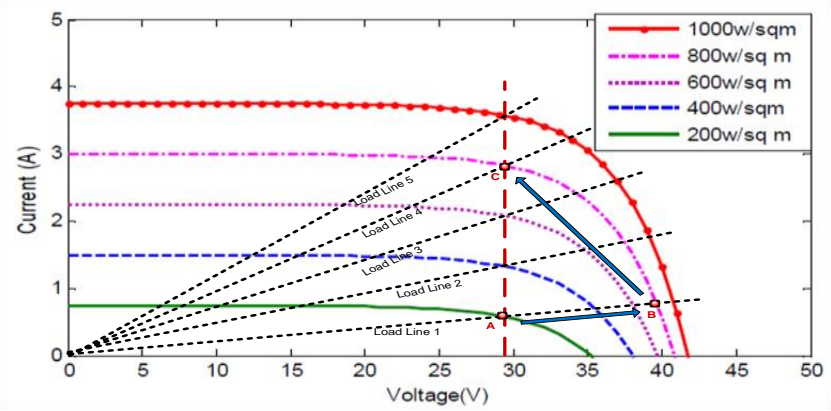

Fig. 8: Proposed Algorithm for increase in solar radiation.

\section{Simulation results}

Figure 9 shows the simulation results of conventional MPPT algorithm. Initially the irradiance is at $500 \mathrm{w} / \mathrm{m}^{2}$ and it is increased to $800 \mathrm{w} / \mathrm{m}^{2}$ at $0.5 \mathrm{sec}$. From 0 to $0.5 \mathrm{sec}$ PV panel produces a voltage of 20v and it is varying in nature which is shown in fig 9 (a). When the irradiance is increased from 500 to $800 \mathrm{w} / \mathrm{m}^{2}$ panel takes some delay to take the change in voltage. But in proposed algorithm the change in voltage is clearly seen at $0.5 \mathrm{sec}$ which is shown in fig 10 (a). In proposed circuit the voltage, current and power is in steady state.

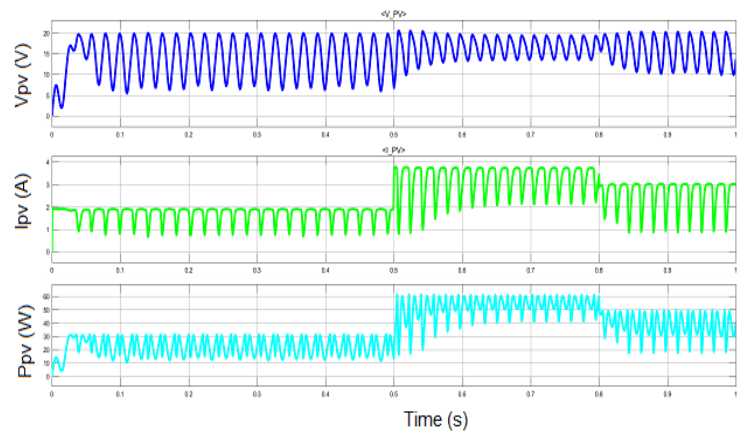

Fig. 9: Results of Conventional Simulation (a) PV voltage (b) PV Curren (c) PV Power.

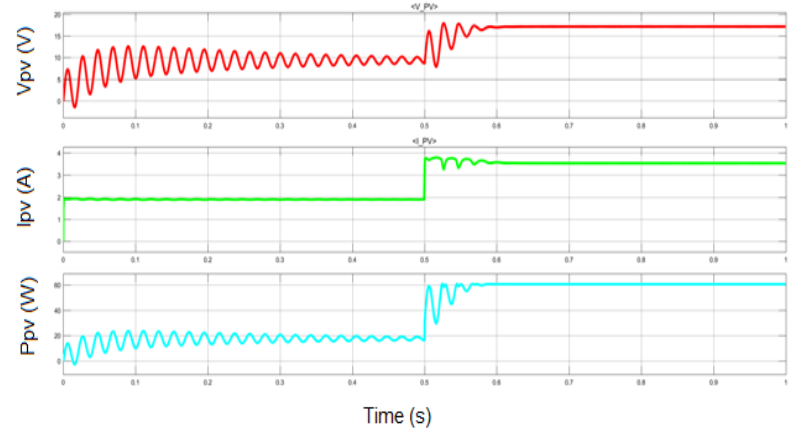

Fig. 10: Results of Proposed Simulation (A) PV Voltage (B) PV Current (C) PV Power.

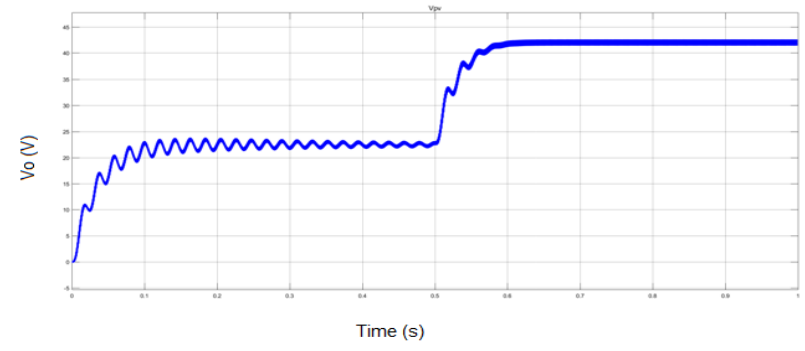

Fig. 11: Results of Output Voltage of Converter

\section{Conclusion}

The proposed algorithm shows better responds to the variation in solar irradiation and variation in load than the conventional algorithm as shown in the simulation. The steady state oscillations is also reduced in the proposed algorithm and thus reduce the power losses. As a conclusion, Fast Acting MPPT Technique for Solar Photovoltaic System under Fast Varying Solar Radiation is proposed and verified

\section{References}

[1] Singh, D., Sharma, N.K., Sood, Y.R., and Jarial, R.K., "Global Status of Renewable Energy and Market: Future Prospectus and Target," Proceedings of International Conference on Sustainable Energy and Intelligent Systems, pp. 171-176, 2011. 
[2] John R. Balfour., Michael L. Shaw., and Sharlave Jarosek., 2013 "Introduction to Photovoltaics," Burlington, Jones \& Bartlett Publishers.

[3] Salameh, Z \& Taylor, D, 'Step-up maximum power point tracker for photovoltaic arrays', Solar Energy, vol. 44, no. 1, pp. 57-61, 1990.

[4] Bader, N, Alajmi, Khaled H, Ahmed, Stephen J, Finney \& Barry W Williams, 'A Maximum Power Point Tracking Technique for Partially Shaded Photovoltaic Systems in Microgrids', IEEE transactions on Industrial Electronics, vol. 60, pp. 1596-1606, 2013.

[5] Villalva, MG, Gazoli, JR \& Filho, ER , 'Comprehensive approach to modeling and simulation of photovoltaic arrays', IEEE Transactions on Power Electronics, vol. 24, no. 5, pp. 1198-1208, 2009.

[6] C. Liang-Rui, T. Chih-Hui, L. Yuan-Li, and L. Yen-Shin, "A biological swarm chasing algorithm for tracking the PV maximum power point," IEEE Trans. Energy Convers., vol. 25, no. 2, pp. 484-493, May 2010

[7] L. Yi-Hwa, H. Shyh-Ching, H. Jia-Wei, and L. Wen-Cheng, "A particle swarm optimization-based maximum power point tracking algorithm for PV systems operating under partially shaded conditions," IEEE Trans. Energy Convers., vol. 27, no. 4, pp. 1027 1035, Nov. 2012.

[8] L. Kui-Jun and K. Rae-Young, "An adaptive maximum power point tracking scheme based on a variable scaling factor for photovoltaic systems," IEEE Trans. Energy Convers., vol. 27, no. 4, pp. 1002-1008, Nov. 2012.

[9] R. A. Mastromauro, M. Liserre, and A. Dell'Aquila, "Control issues in single-stage photovoltaic systems: MPPT, current and voltage control," IEEE Trans. Ind. Informat., vol. 8, no. 2, pp. 241-254, Apr. 2012.

[10] T. Esram and P. L. Chapman, "Comparison of photovoltaic array maximum power point tracking techniques," IEEE Trans. Energy Convers., vol. 22, no. 2, pp. 439-449, May 2007.

[11] A. Al Nabulsi and R. Dhaouadi, "Efficiency optimization of a DSP-based standalone PV system using fuzzy logic and dual-MPPT control," IEEE Trans. Ind. Informat., vol. 8, no. 3, pp. 573-584, Jul. 2012.

[12] T. L. Kottas, Y. S. Boutalis, and A. D. Karlis, "New maximum power point tracker for PV arrays using fuzzy controller in close cooperation with fuzzy cognitive networks," IEEE Trans. Energy Convers., vol. 21, no. 3, pp. 793-803, Aug. 2006.

[13] C. Chian-Song, "T-S fuzzy maximum power point tracking contro of solar power generation systems," IEEE Trans. Energy Convers., vol. 25 , no. 4 , pp. $1123-1132$, Nov. 2010.

[14] L. Zhang, W. G. Hurley, and W. H. Wölfle, "A new approach to achieve maximum power point tracking for PV system with a variable inductor," IEEE Trans. Power Electron., vol. 26, no. 4, pp. 1031-1037, Jun. 2011.

[15] M. Qiang, S. Mingwei, L. Liying, and J.M. Guerrero, "A novel improved variable step-size incremental-resistance MPPT method for PV systems," IEEE Trans. Ind. Electron., vol. 58, no. 6, pp. 2427 2434, May 2011.

[16] L. Whei-Min, H. Chih-Ming, and C. Chiung-Hsing, "Neuralnetworkbased MPPT control of a stand-alone hybrid power generation system," IEEE Trans. Power Electron., vol. 26, no. 12, pp 3571-3581, Dec. 2011

[17] A. Ahmed, L. Ran, S. Moon, and J. H. Park, "A fast PV power tracking control algorithm with reduced power mode," IEEE Trans. Energy Convers., vol. 28, no. 3, pp. 1-11, Aug. 2013.

[18] B. N. Alajmi, K. H. Ahmed, S. J. Finney, and B. W. Williams, "Fuzzylogic- control approach of a modified hill-climbing method for maximum power point in microgrid standalone photovoltaic system," IEEE Trans. Power Electron., vol. 26, no. 4, pp. 1022 1030, Jun. 2011

[19] M. A. G. de Brito, L. Galotto, L. P. Sampaio, G. de Azevedo e Melo, and C. A. Canesin, "Evaluation of the main MPPT techniques for photovoltaic applications," IEEE Trans. Ind. Electron., vol. 60, no. 3, pp. 1156-1167, Mar. 2013

[20] X. Weidong and W. G. Dunford, "A modified adaptive hill climbing MPPT method for photovoltaic power systems," in Proc. IEEE 35th Аnnu. Power Electron. Spec. Conf., 2004, vol. 3, pp. $1957-$ 1963.

[21] Santos LJL, Antunes F, Chehab A and Cruz, 'A maximum power point tracker for PV systems using a high performance boost converter'. Solar Energy, vol. 80, no. 7 pp. 772-778, 2006

[22] Al-Atrash H, Batarseh and Rustom K 2005, 'Statistical modeling of DSP-based hill-climbing MPPT algorithms in noisy environments', Applied Power Electronics Conference and Exposition, APEC'05 IEEE, vol. 3, pp. 1773-1777, 2005.
[23] Fangrui L, Yong K, Yu A and Shanxu D , 'Comparison of P\&O and hill climbing MPPT methods for grid connected PV converter', Proceedings of ICIEA, pp. 804-807, 2008.

[24] Azadeh Safari and Saad Mekhilef, 'Simulation and hardware implementation of incremental conductance MPPT with direct control method using cuk inverter', IEEE Transactions on Industrial Electronics, vol. 58, pp. 1154-1161, 2011.

[25] Hohm D and Ropp M, 'Comparative study of maximum power point tracking algorithms', Progress In Photovoltaic: Research and Applications, vol. 11, pp. 47-62, 2003.

[26] Agarwal V and Patel H, 'Maximum power point tracking scheme for PV systems operating under partially shaded conditions', IEEE Trans. Ind. Electron., vol. 55, pp. 689-1698, 2008.

[27] Moacyr Aureliano Gomes de Brito, Luigi Galotto and Leonardo Poltronieri Sampaio, 'Evaluation of the main MPPT techniques for photovoltaic applications', IEEE Transactions on Industrial Electronics, vol. 60, no. 3, pp. 1156-1167, 2013.

[28] Esram T and Chapman PL, 'Comparison of Photovoltaic array maximum power point tracking techniques', IEEE Transaction on Energy Conversion, vol. 22, no. 2, pp. 439-449, 2007.

[29] L. Fangrui, D. Shanxu, L. Fei, L. Bangyin, and K. Yong, "A variable step size INC MPPT method for PV systems," IEEE Trans. Ind. Electron., vol. 55, no. 7, pp. 2622-2628, Jun. 2008.

[30] Y. Zhou, F. Liu, J. Yin, and S. Duan, "Study on realizing MPPT by improved incremental conductance method with variable step-size," in Proc. 3rd IEEE Conf. Ind. Electron. Appl., 2008, pp. 547-550.

[31] M. Sokolov and D. Shmilovitz, "Load line emulation based maximum power point tracking," in Proc. Power Electron. Spec. Conf., 2008, pp. 4098-4101.

[32] M. Sokolov and D. Shmilovitz, "A modified MPPT scheme for accelerated convergence," IEEE Trans. Energy Convers., vol. 23, no. 4, pp. 1105-1107, Dec. 2008.

[33] S. Patel and W. Shireen, "Fast converging digital MPPT control for photovoltaic (PV) applications," in Proc. Power Energy Soc. Gen. Meeting, 2011, pp. 1-6.

[34] Mohammedi A, Mezzai N, Rekioua D and Rekioua T, 'Impact of shadow on the performances of a domestic photovoltaic pumping system incorporating an MPPT control: A case study in Bejaia, North Algeria', Energy Conversion and Management, 2014, vol. 84 , pp. $20-29$.

[35] Mutlu Boztepe, Francesc, GuinjoanGuillermo, Velasco-Quesada, Santiago Silvestre, Aissa Chouder and Engin Karatepe, 'Global MPPT Scheme for Photovoltaic String Inverters Based on Restricted Voltage Window Search Algorithm', IEEE Transactions on Industrial Electronics, 2014, vol. 61, pp. 3302-3012.

[36] Soon, T.K. and Mekhilef, S. (2015) "A Fast-Converging MPPT Technique for Photovoltaic System Under Fast-Varying Solar Irradiation and Load Resistance" IEEE Transactions on Industrial Inf matics, Volume 11, Issue 1. 